\title{
Kada obveze iz ugovora o javno-privatnom partnerstvu i koncesijama postaju dio duga opće države? ${ }^{1}$
}

\author{
ANTO BAJO, Institut za javne financije \\ DAMIR JURIČIĆ, Agencija za investicije i konkurentnost
}

Korištenje koncesija i ugovora o javno-privatnom partnerstvu (JPP) za financiranje javnih investicija često je motivirano željom vlada da izbjegnu zaduživanje, rast proračunskog deficita i duga opće države. Svrha je rada pokazati statisticki tretman transakcija koji proizlazi iz ugovora o koncesiji i JPP-u, a koji bi se zbog nedostatka proračunskih prihoda mogli učestalije koristiti u financiranju projekata od državnog interesa u Republici Hrvatskoj.

\section{UVOD}

U posljednjih se nekoliko godina u stručnoj i široj javnosti u Europi i Hrvatskoj često raspravlja o utjecaju ugovora o javno-privatnom partnerstvu (JPP) i koncesijama na dug opće države ${ }^{2}$. Rasprave se mogu podijeliti u dvije kategorije - političke i stručne.

Kako bi poslovale u okvirima proračunskih ograničenja, države javne investicije često ne financiraju samostalno jer to podrazumijeva izvjesne kapitalne rashode, a kod financiranja zaduživanjem to znači i izravan rast duga opće države. Političke rasprave uglavnom su usmjerene na primjenu JPP-a i koncesija kao poželjnih modela financiranja i isporuke javnih investicija bez povećanja duga opće države. U pozadini stručnih rasprava fokus je uglavnom na korištenju JPP-a i koncesija za postizanje veće vrijednosti za novac poreznih obveznika. Iz stručnih se rasprava može zaključiti da primarni razlog odabira JPP-a i koncesija nije

\footnotetext{
${ }^{1}$ Autori se na savjetima i sugestijama zahvaljuju Petru Sopeku, Davoru Galincu i Marku Primorcu.

${ }^{2}$ Rasprave uglavnom proizlaze iz pretpostavke da ugovore o JPP-u i koncesiji ne treba evidentirati u bilanci opće države nego izvanbilančno (engl. off balance sheet). U Hrvatskoj i drugim europskim državama, brojni JPP ugovori i koncesije automatski su evidentirani izvan bilance opće države. Međutim, na temelju određenih odredbi ugovora, može doći do potrebe evidencije u bilanci opće države. Najpoznatiji europski primjer je JPP ugovor u Portugalu (EPEC, 2OII), a u Hrvatskoj koncesija Međunarodne zračne luke Zagreb i JPP dvorane Lora u Splitu.
} 
smanjenje duga opće države nego povećanje kvalitete javnih usluga, smanjenje proračunskih rashoda te što pravednija raspodjela troškova i koristi između postojećih i budućih naraštaja poreznih obveznika.

Čini se da treba korigirati politički pristup, prema kojem je ključni argument za primjenu JPP-a i koncesija u financiranju javnih investicija evidencija imovine kapitalnog projekta izvan statistike duga opće države. Za cjelovitije razumijevanje problema potrebno je proučiti pravila Eurostata za evidenciju ugovora o JPP-u i koncesijama.

\section{Pravila Europske UniJe Za eVIDENGiJU Ugovora O JPP-U I KONGESIJAMA}

U Priručniku za javni dug i deficit - ESA 2010 u poglavlju VI Lizing, licence i koncesije - Eurostat (20I4) objašnjava statistički tretman koncesija i JPP-a, razlikujući ih prema kriteriju rizika potražnje, tj. promjenama u obujmu i cijeni isporučene javne usluge.

Koncesija je dugoročan (obično 30 i više godina) ugovorni odnos između javnog naručitelja (najčešće tijela ili jedinica središnje ili lokalne države) i poduzeća iz privatnog sektora kojem je cilj upravljati postojećom ili novoizgrađenom imovinom te naplaćivati prihode od krajnjih korisnika (Eurostat 20I4: 3OI). Koncesionar preuzima rizik potražnje za uslugama i glavni dio prihoda ostvaruje od prodaje javnih usluga krajnjim korisnicima. ESA 2OIo predviđa standardne ugovore o koncesiji za infrastrukturne objekte koji se mogu komercijalno koristiti. U takvim je ugovorima poduzeće (ili nekoliko poduzeća) odgovorno za ukupne troškove projekta - gradnju, poslovanje i održavanje infrastrukture. Troškove korištenja takvih usluga uglavnom snose krajnji korisnici (kućanstva, poduzeća itd.) i koncesionaru za to plaćaju naknadu. Koncesionar najveći dio prihoda ostvaruje izravnom prodajom dobara i usluga i od davatelja koncesije preuzima više poslovnih rizika (uglavnom rizik potražnje za uslugama i rizik sposobnosti upravljanja imovinom).

Ugovor o JPP-u je dugoročan ugovor između javnih naručitelja kao javnih partnera i poduzeća iz privatnog sektora (izvršitelja) kao privatnih partnera. Javnom je partneru cilj stvoriti uvjete za pružanje javne usluge. Privatni partner će izgraditi, rekonstruirati, održavati, financirati i upravljati imovinom (primjerice, škole, bolnice, zatvori, projekti poboljšanja energetske učinkovitosti i slično) kako bi - uz ugovorenu naknadu - javnom partneru osigurao potrebne uvjete za pružanje javne usluge (liječenje, obrazovanje, sigurnost, osvjetljavanje javnih površina i slično). Privatni partner, pritom, pretežiti dio prihoda ostvaruje naplatom naknade izravno iz proračuna javnog partnera.

Premda su po svojoj prirodi vrlo slični, Eurostat razlikuje koncesije i JPP prema kriteriju izvora - ukoliko privatni partner pretežiti dio prihoda ostvaruje na tržištu, riječ je o koncesijama, a ostvaruje li ga od javnog partnera, onda je to JPP.

\section{KLJUČNE SU DILEME VEZANE UZ UTJECAJ IMOVINE I OBVEZA NA DUG OPǴE DRŽAVE}

Kada država samostalno financira i provodi investicijski projekt, za ukupnu vrijednost imovine projekta povećavaju se proračunski kapitalni rashodi, te posljedično rastu deficit i dug. Projekt tada izravno utječe na bilancu države, tj. nalazi se u bilanci države.

Koncesije i JPP mogu se promatrati kao alternativni modeli financiranja javnih projekata, jer se projekti ne evidentiraju u financijskim izvještajima države, nego u izvještajima privatnih partnera (za državu su oni izvan bilance). Upravo zbog nedostatka proračunskih prihoda i visokih proračunskih deficita, država se odlučuje za financiranje kapitalnih investicija u suradnji s privatnim partnerima, korištenjem koncesija i JPP-a. Međutim, i takvo financiranje, motivirano nedostatkom proračunskih prihoda i visokim deficitom, $\mathrm{u}$

2 NEWSLETTER IoI | A. BAJO i D. JURIČIĆ | Kako obveze iz ugovora o javno-privatnom partnerstvu... | Institut za javne financije 
nekim se slučajevima može tretirati kao neizravno zaduživanje države. Neovisno o tome financira li privatni partner investiciju dugom ili vlastitim kapitalom, ako država snosi većinu rizika te investicije, onda je imovina projekta za državu tzv. pripisani (uračunati) kredit (tj. potencijalni dug). Pritom se plaćanja po ugovoru tretiraju kao otplata kredita. Naime, činjenica je da država u konačnici dobiva imovinu koju nije financirala izravno (zaduživanjem) već neizravno (putem privatnog partnera) kroz koncesije ili JPP, pa se u slučaju klasificiranja projekta u bilancu države dug povećava za vrijednost ukupne imovine projekta. Drugim riječima, imovina se tretira kao da ju je kupio (i u potpunosti financirao) javni partner.

Priručnikom o Europskom sustavu računa ESA2OIo, u sklopu procedure prekomjernog proračunskog deficita, Europska komisija nastoji statistički utvrditi u kojim se uvjetima imovina iz ugovora o JPP-u ili koncesijama može naći u obuhvatu (bilanci) javnog sektora na strani pasive kao pripisani (uračunati) kredit.

U slučaju koncesija i JPP-a država je uvijek pravni vlasnik imovine ili infrastrukture koja se daje u koncesiju ili koja nastaje u okviru JPP-a. Predmet ugovora o koncesiji i JPP-u je ekonomska vrijednost imovine koja se $\mathrm{u}$ razdoblju trajanja ugovora može statistički evidentirati u bilanci države (javnog partnera) ili u bilanci koncesionara (privatnog partnera). Ekonomska vrijednost imovine i njena evidencija u, ili izvan bilance države, kao i utjecaj na dug i proračunski deficit, izravno ovisi o sadržaju ugovora i ugovornih klauzula. Primjerice, ugovor može sadržavati i odredbe kojima država jamči zaduživanja privatnog partnera. Izvori financiranja i davanje jamstava kao i raskidne klauzule ugovora često su ključni razlozi za odluku o klasificiranju imovine, odnosno obveza, u bilanci države, te za posljedicu mogu imati rast duga i proračunskog deficita.

Činjenica da je javni naručitelj sklopio ugovor o JPP-u i/ili o koncesiji ne znači da ugovorena transakcija nema utjecaja na dug opće države. Naziv ugovora u potpunosti je irelevantan za odluku hoće li se imovina evidentirati kao dug opće države. Relevantan je sadržaj ugovora, a posebice ugovoreni potencijalni rizici koje može snositi država kao javni partner ili davatelj koncesije.

U ugovorima o koncesiji ključno je pitanje: tko je ekonomski vlasnik imovine, ${ }^{4}$ odnosno, u čijoj se bilanci evidentira imovina tijekom razdoblja korištenja, kako se evidentiraju primitci (prihodi) iz ugovora i kakav je njihov utjecaj na neto primitke/zaduživanje države?

Izmjene i revizije ugovora o koncesiji mogu značajno utjecati na njihov statistički tretman. Uvjeti koji se odnose na prekid ugovora zbog nemogućnosti ostvarenja njegovih odredbi uvelike određuju prirodu (statistički tretman) ugovora.

Koncesija se smatra dugom države ukoliko je država pružila eksplicitno jamstvo kojim preuzima više od 50 posto koncesionarovog duga, te ukoliko je preuzela većinu rizika povezanih s imovinom. Ključno statističko pitanje jeste klasifikacija imovine uključene u ugovor o JPP-u. Ukoliko je imovina državna, onda izravno utječe na neto posuđivanje/zaduživanje i dug. Ukoliko imovina pripada privatnom partneru, tada neizravno može utjecati na neto posuđivanje/zaduživanje i na dug opće države.

Ugovor o JPP-u pretpostavlja dugoročne ugovorne odnose. Duža ročnost ugovora omogućava javnom partneru odgađanje plaćanja dijela troškova u dužem vremenskom razdoblju - duže razdoblje otplate primljenih usluga koje se projektom pružaju javnom partneru (naručitelju). Važna posljedica dugoročnosti je pravednija raspodjela troškova i koristi između postojećih i budućih generacija korisnika usluga.

U ugovornom razdoblju JPP-a javni naručitelj može biti pravni vlasnik imovine (vlasnik je zemljišta i građevine izgrađene na zemljištu), međutim, ekonomski vlasnik je izvršitelj (privatni partner). Ekonomski

\footnotetext{
3 To je zapravo hipotetski dug koji se evidentira u sklopu procedure prekomjernog proračunskog deficita jer u projektu nisu zadovoljeni svi kriteriji za evidenciju duga izvan bilance javnog sektora. Vrijednost mu je ekvivalentna vrijednosti imovine.

${ }^{4}$ Korištenjem imovine, ekonomski vlasnik ostvaruje koristi i preuzima rizike.
} 
vlasnik je onaj koji korištenjem imovine preuzima poslovne rizike i ostvaruje pravo na korist. Nakon isteka ugovora, javni naručitelj postaje i ekonomski vlasnik imovine.

\section{NAČELO POJEDINOG UGOVORA}

Ugovori o JPP-u i koncesiji uglavnom nisu standardizirani. Stoga, pri tumačenju i klasifikaciji transakcija prema ESA 20Io, glavnu riječ na nacionalnoj razini ima statistička radna skupina stručnjaka koji se bave statistikom deficita i duga države u sklopu Procedure prekomjernog proračunskog deficita. Za metodološke savjete, statistička se skupina može konzultirati i s Eurostatom, koji može tražiti uvid u potpisane ugovore. Odredbe ugovora uvelike utječu na percepciju i statistički tretman transakcija u nacionalnim računima.

Posebni je naglasak na pojedinom ugovoru, jer Eurostat (u državama članicama to radi nacionalni zavod za statistiku) ocjenjuje isključivo već sklopljeni ugovor (s pripadajućim dodacima), a ne radne nacrte nekih zamišljenih budućih ugovora (koji se u praksi možda neće realizirati). Nacionalni uredi za statistiku su mjerodavni za ocjenu konkretnog ugovora i odluku o tomu hoće li se iznos ugovora uključiti u dug opće države. Ukoliko nacionalni statistički ured to zatraži, sva su javna tijela koja sklapaju ugovore o koncesiji ili JPP-u obvezna dostaviti primjerak ugovora iz čijih se odredbi može ustvrditi klasifikacija. U Hrvatskoj je Državni zavod za statistiku (DZS) jedini mjerodavan za konačno izvještavanje Eurostata.

Saznanja o transakcijama Eurostat prikuplja iz tromjesečnih fiskalnih statistika nacionalnih ureda za statistiku, ali i temeljem javno dostupnih informacija iz medija, te temeljem dostupnih informacija može pokrenuti postupak ocjene ugovora.

Država članica i nacionalni statistički ured obično predlažu tretman transakcije, koji Eurostat može, ali i ne mora prihvatiti. Najbolje je Eurostatu pokazati ugovor jer tada može značajno izmijeniti prvobitnu odluku o statističkom tretmanu, donesenu temeljem informacija iz medija. Metodološki savjeti javno su objavljeni na stranicama Eurostata.

\section{TEMELJNI KRITERIJI SVRSTAVANJA OSNOVNIH RIZIKA PROJEKTA}

Europska komisija je zasebnim dokumentima ${ }^{5}$ propisala stotinjak kriterija temeljem kojih se pojedini ugovori svrstavaju u dug opće države, a glavni su: I. alokacija osnovnih vrsta rizika; 2. kriteriji koji se odnose na jamstva; i 3. ostali kriteriji.

\section{I. KRITERIJ ALOKAGIJE OSNOVNIH VRSTA RIZIKA}

Većina rizika ${ }^{6}$ javnog projekta svrstana je u tri grupe, vezane uz građenje, raspoloživost javne građevine i potražnju za javnim uslugama.

Rizici vezani uz građenje se uglavnom odnose na troškove građenja unutar planiranog proračuna i unutar planiranog roka, a snosi ih izvršitelj.

\footnotetext{
${ }_{5}$ U sklopu ESA 2010 (Eurostat, 2OI3), Priručnika za državni deficit i dug (Eurostat, 20I4), te posebnim naputkom o utjecaju ugovora o energetskom učinku na statističke račune (Eurostat, 20I5).

${ }^{6}$ Više o rizicima JPP projekta u AJPP (2014).

4 NEWSLETTER IoI I A. BAJO i D. JURIČIĆ | Kako obveze iz ugovora o javno-privatnom partnerstvu... | Institut za javne financije
} 
Raspoloživost javne građevine je obveza izvršitelja da održava izgrađenu javnu građevinu (koja služi za pružanje javnih usluga) u uporabnom stanju za javnog naručitelja tijekom razdoblja trajanja ugovora. Riječ je o rizicima održavanja građevine i opreme, upravljanja građevinom, održavanja njene funkcionalnosti i slično.

Rizici potražnje za javnim uslugama vezani su uz cijenu i količinu isporučenih javnih usluga. Dakle, kada rizik potražnje snosi izvršitelj, on preuzima rizik prikupljanja prihoda koji ovise o cijeni i količini isporučenih javnih usluga.

Eurostat izričito naglašava da je izvanbilančna evidencija (izvan duga opće države) moguća isključivo ako izvršitelj - osim glavnog rizika građenja - preuzme i rizik potražnje i/ili održavanja njene raspoloživosti. Koncesionar obično preuzima sva tri rizika, dok izvršitelj kod JPP-a preuzima uglavnom rizik građenja i održavanja raspoloživosti građevine (imovine) koja je predmet ugovora.

\subsection{JAMSTVA}

Javni naručitelj daje izvršitelju jamstva za zaduživanje, a Eurostat ih razlikuje kao implicitna i eksplicitna. Izdanim jamstvima prenose se rizici projekta na javnog naručitelja.

Eksplicitna jamstva obično predstavljaju potencijalnu obvezu naručitelja (javnog partnera, koncedenta) prema kreditorima izvršitelja (privatnog partnera, koncesionara) da će neotplaćene obveze podmiriti ukoliko ih ne podmiri izvršitelj. Mogu biti vezana uz kredite izvršitelja, vlastite izvore izvršitelja, minimalni promet, fiksni dio JPP naknade ili financijski doprinos koncesionaru.

Implicitnim jamstvima (skrivenim u ugovornim odredbama) ne iskazuje se jasna obveza namirenja određene nepodmirene obveze izvršitelja (npr. kredita) već obveza provođenja buduće radnje, što - posljedično znači da naručitelj preuzima rizik projekta. Primjerice, u slučaju da izvršitelj ima financijske poteškoće, naručitelj se jamstvom obvezuje da će, u određenom postotku, osigurati dodatne izvore financiranja zajedno s izvršiteljem.

U fokusu Eurostatove analize osobito su zanimljiva jamstva koja proizlaze iz raskidnih klauzula ugovora o JPP-u ili o koncesiji. Ukoliko iz raskidnih klauzula proizlazi da je pretežiti dio rizika projekta prenesen na naručitelja (javnog partnera), kao dug opće države evidentirat će se vrijednost koja je jednaka vrijednosti imovine projekta.

Na primjer, Eurostat dopušta da se javni naručitelj obveže na preuzimanje kredita i vrijednosti cjelokupne imovine u slučaju raskida ugovora koji je uzrokovao javni naručitelj neispunjavanjem ugovornih obveza, no ne dopušta takvo preuzimanje u slučaju raskida ugovora (o koncesiji ili JPP-u) kojeg je prouzročio izvršitelj. Ukoliko je ugovoren takav slučaj, vrijednost - najčešće jednaka vrijednosti imovine projekta - automatski se evidentira u okviru duga opće države, jer takvo preuzimanje predstavlja prijenos rizika projekta na javnog naručitelja tako da nije ostvaren kriterij pretežitog prijenosa rizika projekta na izvršitelja.

Kod JPP projekata temeljenih na osiguranju potpune funkcionalnosti građevine za pružanje javne usluge, ugovaranje fiksnog dijela JPP naknade također se tretira kao jamstvo. Treba voditi računa o visini udjela fiksnog dijela JPP naknade s obzirom na obvezu zadovoljenja pravila pretežitog prijenosa rizika projekta na izvršitelja.

Posebnu pozornost treba posvetiti uvjetima prekida ugovora zbog bankrota privatnog partnera (na primjer zbog prikazivanja lošeg poslovanja ili nemogućnosti pružanja usluga prema uvjetima ugovora u dužem vremenskom razdoblju). Kada privatni partner bankrotira, cijela se ekonomska vrijednost imovine prenosi na državu, osim ako nije potpisan ugovor s novim partnerom. Odredbe o raskidu ugovora često traže od države da preuzme imovinu, kao i sve partnerove obveze (kredite). 


\subsection{OSTALI KRITERIJI}

Postoji niz ostalih kriterija, od kojih treba istaknuti najznačajnije.

Ukoliko je više od 50 posto rizika (tzv. "pravilo 50\%") projekta (vrijednosti izgrađene imovine) preneseno na izvršitelja, transakcija se evidentira izvan duga opće države. Neovisno je li riječ o koncesiji ili JPP-u potrebno je utvrditi ukupne rizike projekta kako bi se dokazalo postojanje pravila 50 posto.

Sličan je slučaj kod rekonstrukcije i proširenja građevine. U tom slučaju vrijednost investicijskog zahvata mora iznositi najmanje 50 posto vrijednosti novoizgrađene građevine. To je pravilo obujma investicijskog zahvata i osobito je važno kod projekata energetske učinkovitosti (npr. javne rasvjete i energetske obnove javnih zgrada).

U ostale značajnije kriterije mogu se ubrojiti i slučajevi kada javni izvršitelj financira dio kapitalnih troškova7 ili reprogramira i refinancira kredite u otplati ${ }^{8}$.

\section{ZAKLJUČAK}

Evidencija projekta izvan duga opće države nije i ne bi trebao biti osnovni razlog primjene JPP-a i koncesija. Ti modeli mogu biti korisni za javne investicije, ali njihovi glavni ciljevi trebaju biti:

- veća vrijednost za novac poreznih obveznika u odnosu na financiranje iz proračuna;

- bolji odnos kvalitete i cijene javne usluge, kako za postojeće, tako i za buduće naraštaje korisnika;

- učinkovitije dugoročno planiranje proračuna zbog ugovorenog ograničenja plaćanja;

- povećanje kulture transparentnog provođenja postupka javne nabave i informiranosti poreznih obveznika o cijeni i kvaliteti javne usluge.

Za ocjenu treba li projekt uključiti u statistički obuhvat duga, mjerodavna su isključivo pravila koja je propisao Eurostat. Eurostat ne daje ex-ante mišljenja za hipotetske (potencijalne) ugovore, već isključivo obavlja ex-post procjenu statističkog tretmana već sklopljenih ugovora. Stoga se u pripremi ugovora javni naručitelji trebaju konzultirati sa stručnjacima i precizirati sve ugovorne odredbe kako bi se znalo hoće li provedba projekta utjecati na dug i deficit opće države. Isto tako, budući da se provedbom kapitalnih investicija preuzimaju dugoročne obveze, u postupku pripreme projekta treba izraditi analizu naručiteljeve sposobnosti podmirenja ugovornih obveza.

U institucionalnom smislu, presudna je dobra koordinacija regulatornih tijela - Ministarstva financija (za koncesije) i Agencije za investicije i konkurentnost ${ }^{9}$ (za JPP) s DZS-om (kao nacionalnim mjerodavnim tijelom za ocjenu pripadnosti imovine projekta u dug opće države).

\footnotetext{
${ }^{7}$ Primjerice, naručitelj se obvezuje da će dio kapitalnih troškova isplatiti odmah po završetku faze građenja. To se ne smatra isplatom radova, nego financiranjem dijela kapitalnih troškova projekta. Izvršitelj je preuzeo rizik građenja, ali isplatom dijela kapitalnih troškova povećana je sklonost banaka i investitora da financiraju projekt.

${ }^{8}$ Do reprogramiranja ili refinanciranja financijskih obveza izvršitelja dolazi zbog promjena na financijskom tržištu (promjene kamatnih stopa ili stopa prinosa na udjele), temeljem kojih bi se izmjenom troškova financiranja mogla ostvariti dodatna korist ili trošak za ugovorne strane. Tada je važno koja ugovorna strana preuzima pojedine rizike.

${ }_{9}^{9}$ Bivša Agencija za javno-privatno partnerstvo.
} 


\section{LITERATURA}

AJPP, 20I4. Rizici u projektima javno-privatnog partnerstva (identifikacija, kvantifikacija i alokacija). Priručnici za pripremu i provedbu modela javno-privatnog partnerstva, br. 8. Zagreb: Agencija za javnoprivatno partnerstvo.

EPEC European PPP Expertise Centre, 20II. New Eurostat's rules on contracts that found the major part of availability payments using tolls collected by or on behalf of the government - The case of the SCUT motorway contract in Portugal.

EPEC European PPP Expertise Centre, 2015. Market Update - Review of the European PPP Market, First half of 2015.

Eurostat, 20I4. Manual on Government Deficit and Debt - Implementation of ESA 2OIO. Luxembourg: Publications Office of the European Union.

Eurostat, 2015. Eurostat Guidance Note, The impact of energy performance contracts on government accounts, Directorate D: GFS and quality, 7. August.

Juričić, D., 2OI5. Ukupni životni troškovi kao kriteriji za sagledavanje troškova javnih investicija. Tim4Pin, (9), 8-2I.

Uredba (EU) br. 549/2013 Europskog parlamenta i Vijeća od 2I. svibnja 2013. o Europskom sustavu nacionalnih i regionalnih računa u Europskoj uniji (Regulation (EU) No 549/20I3 of the European Parliament and of the Council of 2I May 2OI3 on the European system of national and regional accounts in the European Union) - ESA 2010.

Uredba o ugovaranju i provedbi energetske usluge u javnom sektoru, NN II/I5. 